Vol. 32, 1: 3-19, 1987

\title{
Recolonization of the Buildings on a Farm by House Mice
}

\author{
Frederick P. ROWE, Roger J. QUY \& Thomas SWINNEY
}

Rowe F. P., Quy R. J. \& Swinney T., 1987: Recolonization of the buildings on a farm by house mice. Acta theriol., 32, 1: 3-19 [With 7 Tables \& 3 Figs.]

House mice, Mus musculus (Linnaeus, 1758), living in and close to the buildings on a farm were trapped-out. The cleared areas and six hedgerows were monitored for mice, using the mark-recapture trapping technique, over the next two years. The buildings were rapidly recolonized but population growth was limited by deficiencies in resources and by frequent habitat disturbance, the result of farming activities. The populations were highly unstable. Recruitment was near continuous but losses were high, over $50 \%$ of the marked animals disappearing in 6 weeks. Young male mice survived least well. There was no indication of disease or starvation and little evidence of predation. The movements data suggested that dispersal from the birthplace was the major cause of population loss. Fewer house mice appear to exist on arable land in Britain than when corn ricks were built but numbers in farmyard areas are still sufficient to make the infestation of buildings commonplace.

[Mammals and Birds Department, Tolworth Laboratory, Agricultural Science Service, Ministry of Agriculture, Fisheries and Food, Hook Rise South, Tolworth, Surrey KT6 7NF, England]

\section{INTRODUCTION}

The house mouse, Mus musculus (Linnaeus, 1758), is an exceptionally successful and widely distributed rodent, well-adapted to a commensal existence in dwellings, food stores and other indoor habitats in urban and rural areas. It also lives out-of-doors in various parts of the world, populations in some arable and grassland regions increasing at times to plague proportions (Newsome \& Crowcroft, 1971; Pearson, 1963). In Britain, the house mouse is well-established on certain islands (Berry, 1968; Berry \& Jakobson, 1975) but numbers are low in fields on the mainland (Rowe, Taylor \& Chudley, 1963; Rowe \& Swinney, 1977) and outbreaks are unknown (Southern \& Laurie, 1946). Dense populations of mice built up in corn ricks on arable land in former years (Southern \& Laurie, 1946; Southwick, 1958; Rowe, Taylor \& Chudley, 1964) but harvesting practices have changed and numbers in rural areas are now largest in farm buildings. Granaries, mills, animal feed stores, dairies 
and livestock holdings are regularly infested by mice (Rowe, Swinney \& Quy, 1983) and unchecked populations cause considerable economic losses (Bergeron \& d'Astous, 1980).

A number of authors (Evans, 1949; Brown, 1953; Petrusewicz \& Andrzejewski, 1962) have examined a colony of mice occupying a barn or similar rural store but there have been few wider studies of farm populations. Reimer \& Petras (1968) investigated the relative abundance of mice in different habitats on two farms in Ontario and a comparable study has been conducted on a farm in Southern England (Rowe \& Swinney, 1977). Trapping on the farm over 12 months showed that the buildings were permanently infested and that small numbers of mice existed in wasteland bordering the buildings and in hedgerows. The present paper reports on the further study of the populations on this farm. The mice residing in and around buildings were removed and a 2-year live-trapping programme was carried out to monitor the pattern of recolonization.

\section{STUDY FARM AND METHODS}

Marshalls Farm, Kirdford, Sussex is a $\mathbf{1 2 0}$ ha mixed arable and dairy farm. The banked and ditched fields are bordered by hedgerows which are regularly trimmed (1.2 to $1.5 \mathrm{~m}$ high).

The buildings, differing considerably in age, size and design, material and use (Rowe \& Swinney, 1977), are located near an area of open yard (Fig. 1). The milling barn is adjoined by four smaller buildings, a fertiliser store, a calf-pen and two piggeries. The other building on the same side of the yard, an ancillary shed, stands in isolation. The dairy unit on the other side of the yard comprises a milking parlour, a machinery room and a loft for the storage of pelleted feed. Cattle are confined to a half-walled enclosure attached to the rear of the unit. An open-fronted silage store is situated beyond the enclosure. The remaining building, a second cattle enclosure, is at a separate site.

A preliminary inspection showed mice to be present in the milling barn complex, in the dairy unit and in the ancillary shed. The populations were trapped-out, using Longworth traps (Chitty \& Kempson, 1949) and, towards the end of the campaign, Little Nipper snap-traps. Most animals were caught in the first week and patches of a fine dust (basic slag) were then laid at numerous points within each building. The lightly rolled patches were examined for footprints, tailmarks and faeces after each inspection of the traps. Trapping was terminated when no mice were caught and no patches were marked on 5 successive days. Traps were also placed outside the buildings in peripheral vegetation, by discarded machinery and debris. Dust was not laid outside and trapping was concluded when no traps were sprung over 7 days.

All animals were weighed, sexed and examined for body wounds or other physical abnormalities. Lactating (enlarged nipples and active milk glands) and pregnant (macroscopically visible embryos) females were identified. As ages were unknown, individuals were classified as adult $(\geqslant 13 \mathrm{~g})$ or young $(<13 \mathrm{~g})$ by weight (Laurie, 1946; Southwick, 1958; Pelikan, 1981). 
Live-trapping in the cleared, or main buildings was begun 6 weeks after the removall of the residents and the development of new mouse populations was monitored for 2 years, using the capture-mark-recapture technique. Longworth traps, supplied with mixed cereal food and hay bedding, were used. In routine trappinig, 132 traps were placed in the buildings, at ground level, on low inner wall leidges and at eaves height. The traps were numbered and all locations were mappec. Trapping was carried out for 11 consecutive days at intervals of 6 weeks.

The cattle enclosure attached to the dairy unit was not trapped initially as no signs of mice were found. The enclosure contained two hay racks, one at each end of the building, and mice were found established near these 3 months after the study commenced. In each trapping thereafter, 7 traps were set in the hay spilled behind each rack. The second enclosure, which was not fitted with racks, and the silage store were heavily stocked with cattle. They were inspected at regular intervals but there was no evidence of mice in them and neither building was trapped.

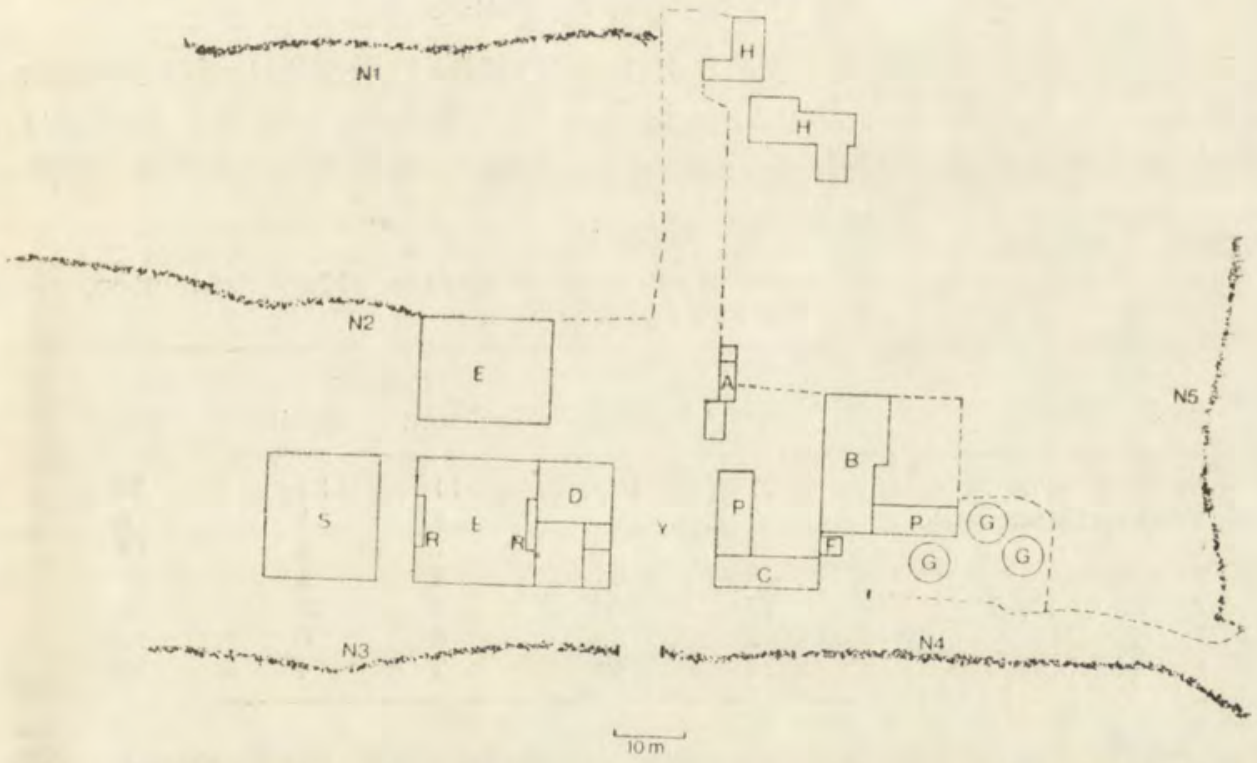

Fig. 1. Location of the buildings and the nearby hedgerows on Marshalls Farm. A: ancillary building; B: milling barn; C: calf-shed; D: dairy unit; E: cattle enclosures; F: food/fertiliser store; G: grain silos; H: farmhouse; N: near hedgerows. (1-5); P: piggeries; R: hay racks; S: silage pit; Y: yard.

Fifty-five traps were operated around the periphery of the buildings. They were set in fringe vegetation, alongside outer walls, by machinery and around silos. Trapping outside the buildings was begun immediately after the completion of the removal campaign. Thereafter, traps were placed inside and outside the buildings simultaneously.

It was not possible to trap every hedgerow on the farm. Five of six hedgerows chosen for examination were located near buildings (Fig. 1). The sixth bordered the far side of an outlying field. The buildings nearest to it, the enclosures and the silage store, were $500 \mathrm{~m}$ away. Each hedgerow was trapped over 4 days in 
the week following the removal of traps from inside and around the buildings. The traps were placed at ground level, $5 \mathrm{~m}$ apart, 20 in each of the near hedgerows and 100 in the far hedgerow.

A morning inspection of the traps was made in all trapping periods. Mice were sexed and weighed and external body wounds recorded. Each animal was marked at first capture and recaptured individuals were identified on all occasions.

Site(s) of capture and recapture were registered throughout. Females were classified pregnant (obviously swollen abdomen), lactating (prominent nipples) or non-breeding. Initially, testes position (abdominal or scrotal) was noted in males but assessment was not always clear-cut and recording was abandoned.

The study was ended by another removal campaign. Trapping was begun immediately after the final monitoring of the populations living in and around the buildings. Captured animals were handled in routine manner, killed and autopsied.

\section{RESULTS}

\subsection{The Resident Populations}

The mice removed from the buildings (Table 1), comprised 84 males and 93 females $(52.5 \%)$. Captures in the milling-barn and the ancillary shed accounted for $71.2 \%$ of the total. Young and adult males were

Table 1

Removal of the original mouse populations (May-June, 1974): distribution, sex and age structure.

\begin{tabular}{lrrrrrr}
\hline & \multicolumn{2}{c}{ Male } & & \multicolumn{2}{c}{ Female } & \\
\cline { 2 - 3 } Site & Young & Adult & & Young & Adult & Total \\
\hline Milling barn & 21 & 16 & 15 & 24 & 76 \\
Food/fertiliser store & 2 & 2 & 1 & 1 & 6 \\
Calf-pen & 3 & 2 & 1 & 8 & 14 \\
Piggeries & 5 & 6 & 4 & 4 & 19 \\
Ancillary shed & 15 & 10 & & 8 & 17 & 50 \\
Dairy unit & 0 & 2 & 4 & 6 & 12 \\
Outside buildings & 12 & 4 & & 2 & 4 & 22 \\
\hline
\end{tabular}

present in similar proportions but young females were significantly outnumbered by adults $\left(\chi^{2}=7.27 ; p<0.01\right)$. Fourteen adult females $(23.3 \%)$ were visibly pregnant and $9(15.0 \%)$ were lactating. Sixteen males and 6 females $(27.3 \%)$ were removed from outside the buildings. Most of the males $(75.0 \%)$ were young animals. Two of the 4 adult females caught were pregnant; one was trapped near the exposed roots of a tree, $8 \mathrm{~m}$ from the nearest building, and the other outside a silo.

\subsection{The Pattern of Recolonization}

The total catch of mice consisted of 316 males and 307 females (Table 2). Slightly more females $(50.6 \%)$ than males were first caught in the buildings but males outnumbered females outside the buildings and in the 
hedgerows. Sex ratios, for each habitat, did not differ significantly from 1:1. Mice caught in separated buildings or both indoors and out-of-doors in the same period were listed by location at first capture (Table 3). Five of the seven main buildings, the piggeries excepted, were recolonized within 6 weeks. Mouse numbers increased during the next 4 months but population growth was not maintained and the largest catch, in any period, amounted to 61 animals. The data indicated a reduction in population size in mid-winter 1976. Small numbers of mice were trapped in January (26) and February (21) of that year and very few young individuals were captured in both months. There was a gradual increase in numbers following this period of decline.

\section{Table 2}

The numbers of new mice caught, marked and released over 2 years: deaths are given in parentheses.

\begin{tabular}{l|rrrrrrr}
\hline \multirow{2}{*}{ Site } & \multicolumn{2}{c}{ Male } & & \multicolumn{2}{c}{ Female } & \\
& Young & Adult & & Young & Adult & Total \\
\hline Milling barn & 41 & $22(2)$ & & $55(1)$ & 20 & 138 \\
Food/fertiliser store & 7 & $9(1)$ & & 13 & 6 & 35 \\
Calf-pen & 24 & 11 & & 32 & 7 & 74 \\
Piggeries & 13 & 3 & & 6 & 4 & 26 \\
Ancillary shed & 9 & $9(1)$ & & 11 & 1 & 30 \\
Dairy unit & 19 & 13 & & 23 & 16 & 71 \\
Cattle enclosure & 55 & 11 & & $48(2)$ & $10(1)$ & 124 \\
Outside buildings & 24 & $30(2)$ & & 37 & 10 & 101 \\
Hedgerows & 5 & 11 & & $4(1)$ & 4 & 24 \\
\hline
\end{tabular}

Thirty-eight mice were caught in the first trapping of the cattle enclosure, all but one, an adult female captured in the dairy unit 6 weeks earlier, being unmarked. The final trapping of the racks, 9 months later, was limited to 4 days because the farmer dismantled them. The number of animals caught in the intervening trapping periods ranged between 14 and 35 (Table 3 ).

Outside the buildings, mice were trapped in small numbers in every period. The data given in Table 3 shows that catches were largest in summer and early autumn, young animals, in particular, being rarely captured in winter.

Very few mice were caught in the hedgerows (Table 3). No new or marked animals were captured in the hedgerow furthest from the buildings throughout the second year. The majority of hedgerow captures were in summer months. No young were caught between November and May. 
Table 3

The number of mice caught in each trapping period and the proportion of young in the catch (MNA: Minimum Number Alive).

\begin{tabular}{|c|c|c|c|c|c|c|c|c|c|c|c|c|c|c|}
\hline \multirow{2}{*}{$\begin{array}{l}\text { Trapping } \\
\text { month }\end{array}$} & \multicolumn{3}{|c|}{ Main buildings } & \multirow[b]{2}{*}{ MNA } & \multicolumn{3}{|c|}{ Cattle enclosure } & \multirow[b]{2}{*}{ MNA } & \multicolumn{3}{|c|}{ Outside buildings } & \multicolumn{3}{|c|}{ Hedgerows } \\
\hline & No. & New & $\%$ Young & & No. & New & $\%$ Young & & No. & New & $\%$ Young & No. & New & $\%$ Young \\
\hline \multicolumn{15}{|l|}{1974} \\
\hline July & - & - & - & - & - & - & - & - & 10 & 10 & 90 & 8 & 8 & 62 \\
\hline Aug. & 17 & 16 & 53 & 17 & - & - & - & - & 7 & 7 & 86 & 3 & 2 & 0 \\
\hline Oct. & 22 & 10 & 18 & 22 & 38 & 37 & 71 & 38 & 20 & 17 & 25 & 7 & 4 & 29 \\
\hline Nov. & 50 & 35 & 32 & 52 & 30 & 22 & 63 & 32 & 9 & 8 & 67 & 0 & 0 & - \\
\hline Dec. & 54 & 28 & 24 & 54 & 23 & 10 & 52 & 28 & 10 & 7 & 30 & 1 & 1 & 0 \\
\hline \multicolumn{15}{|l|}{1975} \\
\hline Feb. & 48 & 19 & 31 & 50 & 35 & 23 & 63 & 39 & 8 & 4 & 37 & 0 & 0 & - \\
\hline Mar. & 47 & 21 & 36 & 54 & 22 & 8 & 59 & 26 & 1 & 0 & 0 & 1 & 0 & 0 \\
\hline May & 61 & 31 & 39 & 64 & 14 & 6 & 36 & 19 & 6 & 3 & 0 & 0 & 0 & - \\
\hline June & 41 & 22 & 44 & 52 & 26 & 17 & 73 & 27 & 9 & 4 & 33 & 1 & 0 & 100 \\
\hline July & 55 & 34 & 60 & 62 & 6 & 1 & 17 & 7 & 10 & 4 & 40 & 3 & 2 & 67 \\
\hline Sept. & 45 & 25 & 49 & 47 & - & - & - & - & 10 & 5 & 40 & 3 & 2 & 33 \\
\hline Oct. & 39 & 14 & 15 & 41 & - & - & - & - & 3 & 1 & 33 & 0 & 0 & - \\
\hline Nov. & 49 & 31 & 51 & 51 & - & - & - & - & 5 & 2 & 20 & 0 & 0 & 一 \\
\hline \multicolumn{15}{|l|}{1976} \\
\hline Jan. & 26 & 4 & 8 & 30 & - & - & - & - & 1 & 0 & 0 & 1 & 1 & 0 \\
\hline Feb. & 21 & 3 & 10 & 26 & - & - & - & - & 3 & 1 & 0 & 0 & 0 & - \\
\hline Mar. & 35 & 20 & 51 & 39 & - & - & - & - & 9 & 9 & 33 & 1 & 1 & 0 \\
\hline May & 35 & 15 & 37 & 35 & - & - & - & - & 4 & 1 & 0 & 0 & 0 & - \\
\hline June & 38 & 25 & 37 & 41 & - & - & - & - & 13 & 8 & 46 & 3 & 3 & 33 \\
\hline Aug. & 49 & 21 & 39 & 54 & - & - & - & - & 12 & 10 & 67 & 0 & 0 & - \\
\hline
\end{tabular}




\subsection{Population Size}

Estimates of population size in the buildings have been based on the minimum number of animals known to have been alive (MNA) during each trapping period. It is assumed that animals which missed capture in a period remained within trapping range. Following the analysis of a mouse population by Petrusewicz \& Andrzejewski (1962), use of the "calendar of catches" or MNA method has been made in studies of fluctuating vole (Krebs, Keller \& Tamarin, 1969; Boonstra, 1977) and deermouse (Taitt, 1981) populations. The work of Hilborn, Redfield \& Krebs (1976) shows that population estimates based on MNA figures are reliable (error less than 10\%) provided that a large proportion (above $55 \%)$ of the animals of trappable age are captured every time. This: provision is met in the present study; trappability, calculated by the method of Taitt (1981), is high, averaging $75 \%$. The MNA figures derived from each trapping of the main buildings and of the cattle enclosure are given in Table 3.

\subsection{Population Turnover}

Disappearance rates were high in all trapped areas. Of the 498 mice: caught in the buildings, 8 died in traps at first capture and 21 were new captures in the final trapping period. Only $215(45.8 \%)$ of the remainder

\section{Table 4}

Survival in the main buildings at different times of the year.

\begin{tabular}{lrcc}
\hline $\begin{array}{c}\text { Trapping } \\
\text { period }\end{array}$ & $\begin{array}{c}\text { Number of } \\
\text { mice }\end{array}$ & $\begin{array}{c}\text { Number present } \\
\text { 6 weeks later }\end{array}$ & $\begin{array}{c}\text { Proportion } \\
\text { surviving }\end{array}$ \\
\hline 1974 & & & \\
July-Sept. & 39 & 22 & 0.56 \\
Oct.-Dec. & 101 & 51 & 0.50 \\
1975 & & 55 & 0.59 \\
Jan--Mar. & 93 & 42 & 0.42 \\
Apr-_June & 99 & 38 & 0.38 \\
July-Sept. & 99 & 41 & 0.47 \\
Oct-Dec. & 88 & 47 & 0.58 \\
1976 & & 40 & 0.56 \\
Jan-Mar. & 81 & & \\
Apr.-June & 71 & & \\
\hline
\end{tabular}

were recaptured after 6 or more weeks, either indoors or out-of-doors. Records of long-term survival were rare. Two animals were recaptured over 1 year. One of these, a male, already adult when it was first caught. 
outside the milling-barn in December 1974, entered the barn soon afterwards and it was last captured there in May 1976. The other, a young female released in the barn in November 1974, remained in the same building until March 1976.

Disappearance within the buildings in different seasons was examined. The number of mice caught in 3-monthly periods and the proportion alive after intervals of 6 weeks were determined (Table 4). The rate of loss did not vary significantly during the year.

The duration of residency in the building corresponding to first capture was also examined. Some mice missed capture in a trapping period and for this reason only the trapping records of those 340 animals at risk of recapture over 30 weeks or longer were analysed. Residence tables were constructed, mice from the same source being grouped at a common

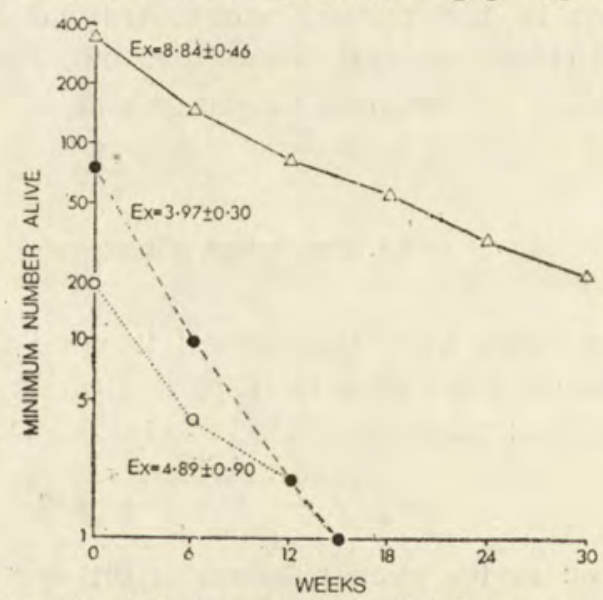

Fig. 2. Survival in relation to site at first capture. $\Delta$ buildings; 0 outside buildings;

$O$ hedgerows. $E x$ is the expectation of life ( \pm 1 S.E.).

origin as if they were caught contemporaneously (Caughley, 1977; Boonstra, 1977; Stickel, 1979). The number of animals surviving was determined for each 6-week trapping interval and expectation of further life was calculated using the method of Leslie et al., (1955). Life expectancy was short, on average less than 9 weeks (Fig. 2). Further analysis, taking sex and age into account, showed that young males had the poorest life expectancy, about 3 weeks shorter than that of young females or of adults of either sex (Fig. 3).

Population losses were still higher in mice marked outside the buildings and in the hedgerows. Of the 112 animals at risk, 25.9\% were recaptured or known to have been alive 6 weeks later. Average life expectancy was about 4 to 5 weeks shorter than that of mice caught in the buildings (Fig. 2). 


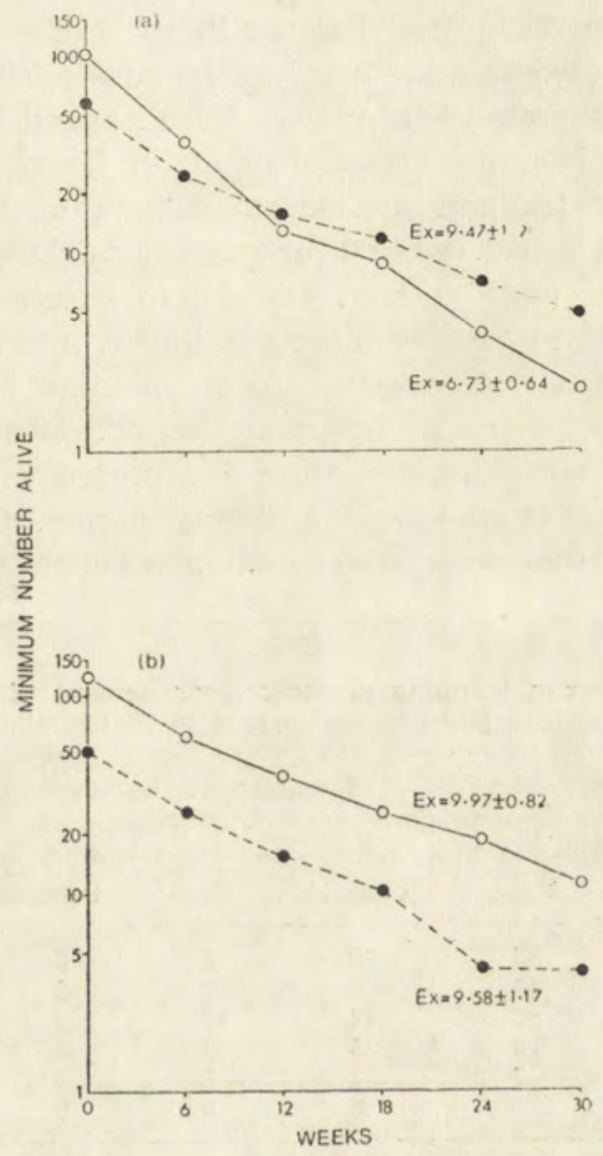

Fig. 3. Survival of males $(a)$ and of females $(b)$ in the main buildings. adult; 0 young. $E x$ is the expectation of life ( \pm 1 S.E.).

\subsection{Movements}

Movements within a single trapping period and between trapping periods were examined, based on the location of each animal at first capture and then at all subsequent captures.

Of the 207 males and 205 females first caught indoors in a trapping period, $86.7 \%$ and $89.8 \%$ respectively were recaptured in the original or in an adjoining building within the same period. The remaining animals were found outside a building $(11.2 \%)$ or in a separated building $(0.7 \%)$. Only 20 of the males $(9.7 \%)$ and 7 of the females $(3.4 \%)$ were located $10 \mathrm{~m}$ or more apart at successive captures.

Change in location was more evident in mice first caught out-of-doors. Of 58 males and 40 females captured outside buildings, $29.3 \%$ and $42.5 \%$ 
respectively were recaptured indoors in the same trapping period; also, 23 of the males $(39.7 \%)$ and 12 of the females $(30.0 \%)$ moved more than $10 \mathrm{~m}$ between successive captures. Mice ranged more widely in the hedgerows. Of 17 animals first caught in hedgerows and recaptured within the same trapping period, movement of $10 \mathrm{~m}$ or more were recorded for 8 males $(72.7 \%)$ and for 3 females $(50.0 \%)$.

The location of mice at first capture in successive trapping periods could be expected to provide more significant information on the moveinents of individuals. The results were similar to those obtained on movements within a single trapping period. Most males $(73.7 \%)$ and females $(87.2 \%)$ found indoors were recaptured in the same or in an adjoining building in the next trapping period. Only 8 males $(8.1 \%)$ and 4 females $(3.4 \%)$ were re-located in a separated building. Table 5

Table 5

Movements between trapping periods: measurement of distance from first capture point in one period to that of the next.

\begin{tabular}{|c|c|c|c|c|c|c|}
\hline \multirow{3}{*}{$\begin{array}{l}\text { Distance between } \\
\text { successive } \\
\text { positions } \\
\text { of capture }(\mathrm{m})\end{array}$} & \multicolumn{6}{|c|}{ Location at first capture point } \\
\hline & \multicolumn{2}{|c|}{$\begin{array}{ll} & \text { Inside } \\
\text { a } & \text { building }\end{array}$} & \multicolumn{2}{|c|}{$\begin{array}{l}\text { Outside } \\
\text { a building }\end{array}$} & \multicolumn{2}{|c|}{$\frac{\text { In }}{\text { a hedgerow }}$} \\
\hline & Male & Female & Male & Female & Male & Female \\
\hline$\leqslant 5$ & 83 & 90 & 8 & 0 & 0 & 0 \\
\hline $6-10$ & 43 & 109 & 1 & 5 & 0 & 0 \\
\hline $11-25$ & 45 & 42 & 10 & 4 & 1 & $n$ \\
\hline $26-50$ & 10 & 5 & 3 & 3 & 0 & 1 \\
\hline $51-100$ & 7 & 2 & 3 & 5 & 2 & 1 \\
\hline$>100$ & 1 & 0 & 0 & 0 & 1 & 1 \\
\hline
\end{tabular}

gives the distance between points of capture for all paired events. Of the 437 registered movements, $325(74.4 \%)$ were less than $10 \mathrm{~m}$. In contrast, 10 males and 5 females caught outside the buildings were recaptured indoors in the next trapping period and $28(66.7 \%)$ of the movements were $10 \mathrm{~m}$ or more (Table 5). Seven animals were released in the hedgerows and recaptured in a subsequent trapping period. Only one of these was still living in a hedgerow; the remainder were recaptured inside or around a building. Five of the mice were located $>50 \mathrm{~m}$ apart in successive trapping periods.

\subsection{Breeding}

Three adult females, all in breeding condition, were caught in the buildings on the first occasion and pregnant or lactating individuals were found in all except o e (January 1976) trapping period. Indoors, 247 adult females were examined, of which $61(24.7 \%)$ were visibly pregnant and 
$30(12.1 \%)$ were lactating. The proportion of breeding females ranged between $23.9 \%$ in the calf-shed and $43.5 \%$ in the dairy unit. In both years, breeding intensity decreased in autumn and winter (Table 6).

Breeding performance was comparable in the cattle enclosure. Fortyone adult females were examined over the 10-month trapping period; $10(24.4 \%)$ of them were pregnant and $5(12.2 \%)$ were lactating. Also similarly, fewer breeding females were found in late autumn and winter $(17.4 \%)$ than in other trapping months $(61.1 \%)$.

\section{Table 6}

Breeding performance of adult female mice in the buildings.

\begin{tabular}{lccccc}
\hline \multicolumn{1}{c}{ Period } & & $\begin{array}{c}\text { Total } \\
\text { number }\end{array}$ & $\begin{array}{c}\text { Number } \\
\text { pregnant }\end{array}$ & $\begin{array}{l}\text { Number } \\
\text { lactating }\end{array}$ & $\begin{array}{c}\% \\
\text { breeding }\end{array}$ \\
\hline July-Sept. & 1974 & 13 & 4 & 3 & 54 \\
Oct.-Dec. & 1974 & 32 & 7 & 1 & 25 \\
Jan.-Mar. & 1975 & 30 & 8 & 3 & 37 \\
Apr.-June & 1975 & 30 & 9 & 5 & 47 \\
July-Sept. & 1975 & 27 & 8 & 5 & 48 \\
Oct.-Dec. & 1975 & 35 & 6 & 5 & 31 \\
Jan.-Mar. & 1976 & 39 & 5 & 4 & 23 \\
Apr-June & 1976 & 23 & 6 & 4 & 44 \\
July-Aug. & 1976 & 18 & 8 & 0 & 44 \\
\hline
\end{tabular}

Table 7

Removal of the new mouse populations (August-September, 1976): distribution, sex and age structure.

\begin{tabular}{lcccccrr}
\hline \multirow{2}{*}{ Site } & \multicolumn{2}{c}{ Male } & & \multicolumn{2}{c}{ Female } & \\
\cline { 2 - 3 } & Young & Adult & & Young & Adult & & Total \\
\hline Milling barn & 2 & 4 & & 2 & 3 & 11 \\
Food/fertiliser store & 2 & 2 & & 8 & 5 & 17 \\
Calf-pen & 1 & 2 & & 0 & 5 & 8 \\
Piggeries & 1 & 3 & & 4 & 1 & 9 \\
Ancillary shed & 4 & 1 & & 2 & 2 & 9 \\
Dairy unit & 4 & 6 & 2 & 2 & 14 \\
Outside buildings & 5 & 3 & 6 & 0 & 14 \\
\hline
\end{tabular}

Twenty-seven adult females were caught outside the buildings, of which $4(14.8 \%)$ were pregnant and $6(22.2 \%)$ were lactating. Samples were small but no breeding females were trapped in winter months, suggesting that breeding was seasonal. The 5 adult females captured in the hedgerows were in non-breeding condition. Nine young animals were also caught however, all in summer months, indicating that some breeding occurred at that time of year. 


\subsection{Population Removal}

Sixty-eight mice (32 males, 36 females) were trapped-out in the buildings. The largest population was removed from the smallest building, the fertiliser/food store (Table 7). A further 8 males and 6 females were trapped outside the buildings. Thirty-four $(87.2 \%)$ of the adults taken in the removal trapping were marked individuals, an indication that most recruits were captured in the study period.

\section{DISCUSSION}

House mice infest a wide range of farm buildings but living conditions are highly variable and population size differs considerably (Rowe, Swinney \& Quy, 1983). The work of Anderson (1962) has shown that small granaries on prairieland in Canada supported a single breeding unit or deme of mice, each store containing about 10 weaned animals of which 4 to 7 were reproductively active. Food was available in excess and predators were absent but escape cover and nesting facilities on the surface of the grain were poor and numbers were regulated by the emigration of young. Comparable populations have been found living in grain silos in English farmyards (Wadsworth \& Wainman, 1979). Workshops, equipment sheds, offices and other ancillary buildings support slightly larger populations (average size 22) when they are additionally used as temporary food stores (Rowe, Swinney \& Quy, 1983). Buildings holding grain and feeding stuffs in bulk and intensive stock-rearing units are invariably more heavily infested, particularly when the mice in them have access to wall and roof cavities. Numbers may build-up rapidly when food, cover and living space co-exist, the populations in some poultry houses, for example, increasing to several thousands in 15 to 18 months (Norris, 1973).

Recent experimental work on the control of house mice on farms (see for example Rowe, Plant \& Bradfield, 1981) has shown that a depopulated building is usually re-infested within weeks by immigrants from neighbouring buildings. In the present study, mice were first removed from a whole complex of buildings and also from their immediate vicinity. Nevertheless, new animals, mainly young, were caught outside the buildings in the next 2 weeks (Table 3 ) and immigrants were captured 6 weeks later. Mouse numbers out-of-doors in later summer, when livetrapping began, were sufficient therefore to provide colonists for the buildings. Newsome (1962) has reported on reservoirs of mice occupying marginal habitat (reed-beds) remote from farm buildings, neighbouring wheatfields being invaded in spring and summer of each year.

The buildings on Marshalls Farm, despite their early recolonization, 
failed to support large numbers of mice. Living conditions seldom remained optimum for long and the limited growth of the new populations can be attributed to deficiencies in resources, their irregular distribution, and to major habitat changes resulting from farming activities. Thus, grain was milled in one corner of the large barn and alternative food was scarce; the walls and floor of the barn were also un-lined, restricting living space. The small store supported few mice until, late-on, the fertiliser was replaced by animal feed. Bedding straw provided ideal harbourage for mice in the piggeries but it was heavily trampled by the pigs and these animals wasted little food. The trapping data indicated that the mice caught in the piggeries were resident in the barn or in the calf-pen. Grain was initially stored in the calf-pen and mice nested in the straw bales used to confine it. Numbers declined after 4 month however when beet pulp was stored instead and they remained low throughout the second year, during which calves were periodically installed in separate pens. Older, free-ranging calves were kept in the ancillary building on three occasions; mice lived at eaves height but there were few crevices in the stone walls and numbers fell each time the stock was cleared out. The dairy loft was permanently supplied with pelleted cattle feed, an excellent diet for mice (Rowe, Swinney \& Quy, 1983), but living space was limited and nesting material was in very short supply. Mice thrived best in the cattle enclosure fitted with hayracks. The spilled hay provided food in the form of grass and weed seeds, dense cover and favourable nesting material. The two rack populations, moreover, remained undisturbed for 10 months. Most of the mice disappeared when the racks were dismantled, only 5 of them being subsequently recaptured in other trapped areas.

The indoor populations were thus in a constant state of flux, their size and composition changing continuously. Losses were consistently high, over $50 \%$ of the marked animals disappearing within 6 weeks. Mice were resident, on average, for only 8.8 weeks, females surviving for about 2 weeks longer than males. These findings closely resemble those reported on mice occupying a barn (Brown, 1953) and a loft (Petrusewicz \& Andrzejewski, 1962). Further analysis of our residency data (Fig. 3) showed that young males had the shortest life expectancy. Singleton (1983) studied a colony of mice in an aviary and likewise found that juvenile males survived the poorest, only $21 \%$ of them being recaptured as adults compared to $38 \%$ of the juvenile females.

Little information is available on the fates of the mice which disappeared from the buildings. Eight animals died in traps and 6 carcasses were found, 5 indoors and one out-of-doors. There was no obvious sign of disease (Piper, 1928; Fenyuk, 1941; Pearson, 1963), or, judging from 
the regular increase in body-weight, of starvation (Evans, 1949). The infrequent catch of young in mid-winter 1976 coincided with a period of intensely cold weather, the environmental condition considered to be of extreme hazard to mice in the field (Jakobson, 1978). No dead animals were found however and the captured adults appeared to be in good physical condition. Breeding activity was lowest during this period (Table 6), and it is probable that the decline in numbers was the result of a decrease in litter production rather than an increase in juvenile mortality.

Predators could easily have accounted for the losses but, as in most field situations (Berry, 1981), predation is not thought to have been significant. No barn owls (Tyto alba) or other avian predators were observed indoors and no cats (Felis domesticus) were kept on the farm. A weasel (Mustela nivalis) was trapped in the barn and a partly eaten mouse was found outside a rat (Rattus norvegicus) burrow. Rats were established in the vicinity of the karn on two occasions but both colonies were quickly eradicated at the request of the farmer. The mouse populations behind the hay-racks lived an extremely well-sheltered existence but mice also disappeared rapidly from these sites. This finding, above all, indicated that predation was not a major cause of the population losses.

There is more evidence to suggest the occurrence of movement outof-doors. Fifty-one indoor-marked animals were last captured at a different site, outside a building (37), in a separated building (12) or in a hedgerow (2). Thirty-four $(69.4 \%)$ of them were males, most of which, considering their body-weight, were evidently young when they moved. The conclusion from the movements data that young male mice were principal emigrants is in keeping with their particularly rapid disappearance indoors (Fig. 3).

Intensive trapping of hedgerows in the present study yielded far fewer house mice than native mice or voles. In former years, Southern \& Laurie (1946) and Rowe, Taylor \& Chudley (1963) found that house mice were more common in hedgerows, particularly in those parts close to corn ricks. The bulk handling of grain and the installation of drying equipment has virtually eradicated ricks from the English countryside, thereby removing the principal resorvoirs of over-wintering mice. It seems probable, from the infrequent catch of mice in hedgerows in our study, that the general level of populations in field situations has been lowered as a result. This study also showed however that suitable habitats are still available to mice in farmyards and that sufficient numbers of animals exist in them to ensure the infestation of any building providing food and shelter. 
Acknowledgements. We are grateful to Dr. W. P. Crowcroft for helpful discussions and constructive comments on this manuscript. Mr. C. J. Plant gave valuable assistance in the field. We thank Mr. E. Lywood for his interest and permission to work on Marshalls Farm.

\section{REFERENCES}

1. Anderson P. K., 1970: Ecological structure and gene flow in small mammals. Symp. Zool. Soc. Lond., 26: 299-325.

2. Bergeron J. M. \& Astous G. De., 1980: House mouse populations in different farm buildings and livestock feed losses. Can. J. Agric. Econ., 28: 77-82.

3. Berry R. J., 1968: The ecology of an island population of the house mouse. J. Anim. Ecol., 37: 445-470.

4. Berry R. J., 1981: Population dynamics of the house mouse. Symp. Zool. Soc. Lond., 47: 395-425.

5. Berry R. J. \& Jakobson M. E., 1975: Adaptation and adaptability in wild-living house mice. J. Zool. Lond., 176: 391-402.

6. Boonstra R., 1977: Effect of conspecifics on survival during population declines in Microtus townsendii. J. Anim. Ecol., 46: 835-851.

7. Brown R. Z., 1953: Social behaviour, reproduction and population changes in the house mouse (Mus musculus L.). Ecol. Mongr., 23: 217-240.

8. Caughley G., 1977: Analysis of Vertebrate Populations. Wiley, London \& New York.

9. Chitty D. \& Kempson D. A., 1949: Prebaiting small mammals and a new design of live trap. Ecology, 30: 536-542.

10. Evans F. C., 1949: A population of house mice (Mus musculus) following a period of local abundance, J. Mammal., 30: 351-363.

11. Fenyuk B. K., 1941: The mass increase of mouse-like rodents in the south-east of the R.S.F.S.R. in 1937. [In: "Rodents and rodent control" 1: 209-224]. Saratov: State Inst. Microbiol. \& Epidemiol, for the south-east of the U.S.S.R. [In Russian].

12. Hilborn R., Redfield J. A. \& Krebs C. J., 1976: On the reliability of enumeration for mark and recapture census of voles Can. J. Zool., 54: 1019-1024.

13. Jakobson M. E., 1978: Winter acclimatization and survival of wild house mice. J. Zool, Lond., 185: 93-104.

14. Krebs C. J., Keller B. L. \& Tamarin R. H., 1969: Microtus population biology: demographic changes in fluctuating populations of $M$. ochrogaster and $M$. pennsylvanicus in southern Indiana. Ecology, 50: 587-607.

15. Laurie E. M. O., 1946: The reproduction of the house mouse (Mus musculus) living in different environments. Proc. R. Soc. (B)., 133: 248-281.

16. Leslie P. H., Tener, J. S., Vizoso M. \& Chitty, H., 1955: The longevity and fertility of the Orkney vole, Microtus orcadensis, as observed in the laboratory. Proc. Zool. Soc. Lond., 125: 115-125.

17. Newsome A. E., 1969: A population study of house-mice permanently inhabiting a reed-bed in South Australia. J. Anim. Ecol., 38: 361-377.

18. Newsome A. E. \& Crowcroft W. P., 1971: Outbreaks of house mice in South Australia in 1965. CSIRO Wildl. Res., 16: 41-47.

19. Norris J., 1973: Keeping mice out of their favourite home. Poult. Wld., 124: 16-17.

20. Pearson O. P., 1963: History of two local outbreaks of feral house mice. Ecology, 44: 540-549. 
21. Pelikan J., 1981: Patterns of reproduction in the house mouse. Symp. Zocl. Soc. Lond., 47: 205-229.

22. Petrusewicz K. \& Andrzejewski R., 1962: Natural history of a free-living population of house mice (Mus musculus L.) with particular reference to groupings within the population. Ekol. pol. (A)., 10: 85-122.

23. Piper S. E., 1928: The mouse infestation of Buena Lake Basin, Kern County, California, September 1926 to February 1927. Month. Bull. Calif. Dept. Agric., 17: $538-560$.

24. Reimer J. D. \& Petras M. L., 1968: Some aspects of commensal populations of Mus musculus in south-western Ontario. Can. Fld. Nat., 82: 32-42.

25. Rowe F. P., Plant C. J. \& Bradfield A., 1981: Trials of the anticoagulant rodenticides bromadiolone and difenacoum against the house mouse (Mus musculus L.). J. Hyg. Camb., 87: 171-177.

26. Rowe F. P., Taylor E. J. \& Chudley A. H. J., 1963: The numbers and movements of house mice (Mus musculus L.) in the vicinity of four corn ricks. J. Anim. Ecol., 32: 87-97.

27. Rowe F. P., Taylor E. J. \& Chudley A. H. J., 1964: The effect of crowding on the reproduction of the house mouse (Mus musculus L.) living in corn ricks. J. Anim. Ecol., 33: 477-482.

28. Rowe F. P. \& Swinney T., 1977: Population dynamics of small rodents in farm buildings and on arable land. EPPO Bull., 7: 431-437.

29. Rowe F. P., Swinney T. \& Quy R. J., 1983: Reproduction of the house mouse (Mus musculus L.) in farm buildings. J. Zool. Lond., 199: 259-269.

30. Singleton G. R., 1983: The social and genetic structure of a natural population of house mice, Mus musculus, at Healesville Wildlife Sanctuary. Aust. J. Zool., 31: $155-166$.

31. Southern H. N. \& Laurie E. M. O., 1946: The house mouse (Mus musculus) in corn ricks. J. Anim. Ecol., 15: 135-149.

32. Southwick C. H., 1958: Population characteristics of house mice living in English corn ricks: density relationships. Proc. Zool. Soc. Lond., 131: 163-175.

33. Stickel L. C., 1979: Population ecology of house mice in unstable habitats. J. Anim. Ecol., 48: 871-887.

34. Taitt M. H., 1981: The effect of extra food on small rodent populations. Deermice (Peromyscus maniculatus). J. Anim. Ecol., 50: 111-124.

35. Wadsworth J. T. \& Wainman H. E., 1979: Control of rodents in butylrubber silos using aluminium phosphide preparations. Int. Pest Control., 27: 132-138.

Received, February 17, 1986. Accepted, July 30, 1986.

Frederick P. ROWE, Roger J. QUY i Thomas SWINNEY

REKOLONIZACJA ZABUDOWAŃ FARMY PRZEZ MYSZ DOMOWA

\section{Streszczenie}

Wyłowiono myszy domowe (Mus musculus Linnaeus, 1758) żyjące wewnątrz i w pobliżu zabudowań farmy (Ryc. 1, Tabela 1). Na oczyszczonym w ten sposób terenie oraz wzdłuż sześciu pasów żywopłotu ustawiono pułapki i w ciągu dwóch kolejnych lat łowiono myszy domowe metodą CMR (Tabela 2). Zabudowania były 
bardzo szybko rekolonizowane, ale niedostatki zasobów oraz częste zaburzenia środowiska wynikające $\mathrm{z}$ prac gospodarskich na farmie ograniczały wzrost populacji myszy. Wchodzenie nowych osobników do populacji odbywalo się przez cały prawie rok, lecz straty byly wysokie: ponad $50 \%$ znakowanych myszy znikało w ciągu 6 tygodni od pierwszego złowienia (Ryc 2 i 3). Najgorzej przeżywały młode samce (Tabela 3 i 4). Nie uzyskano żadnych danych dotyczących ubytków z powodu chorób, niedożywienia i nieznaczne dane na temat ubytków powodowanych przez drapieżniki. Dane o przemieszczeniach (Tabela 5) sugerują, że opuszczanie miejsca urodzenia było najczęstszą przyczyną strat. Odkąd z rolniczego krajobrazu Wielkiej Brytanii zniknęły stogi zboża, tylko nieliczne myszy domowe żyją na polach ornych w czasie zimy. Liczebność populacji zasiedlających tereny farm jest jednak wystarczająco wysoka (Tabela 6 i 7), aby każdego roku następowało zasiedlanie przez myszy wszelkich budynków zapewniających pokarm i ukrycie. 